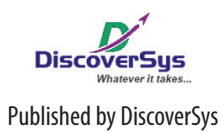

Published by DiscoverSys

\title{
The correlation between knowledge, body image perception and self efficacy with anxiety among perimenopausal women in Dauh Puri Klod Village,
} Bali

\author{
Ni Made Ayu Yulia Raswati Teja, ${ }^{1 *}$ Ni Komang Ekawati, ${ }^{2}$ Ni Made Swasti Wulanyani ${ }^{3}$
}

\section{ABSTRACT}

Background and purpose: Level of anxiety among women approaching menopause is often high. This is influenced by knowledge, education, culture and customs, body image perception and selfefficacy. This study aims to determine the relationship between knowledge, perception of body image and self-efficacy with anxiety in perimenopausal women.

Methods: This study employed a cross sectional design with 87 perimenopausal women aged 45-55 years in Dauh Puri Klod Village, Denpasar City, Bali Province. Respondents were selected with systematic random sampling from 1,039 women aged 45-55 years recorded in Dauh Puri Klod Village. Interviews were conducted at each respondent's house in August 2018. Data collected included sociodemographic characteristics, knowledge, perception of body image, self-efficacy and anxiety levels among women approaching menopause. Bivariate analysis with chi square test and multivariate analysis with logistic regression were conducted to identify the association between variables.

Results: The results of bivariate analysis showed that variables associated with anxiety were knowledge $(p=0.001)$, perception of body image $(p=0.012)$ and self-efficacy $(p=0.001)$. The results of multivariate analysis with the backward method showed that the variables associated with anxiety were knowledge ( $A 0 R=10.83$; 95\%Cl: 3.31-35.37) and self-efficacy ( $A O R=3.48 ; 95 \% \mathrm{Cl}: 1.09-11.14)$. Conclusion: Knowledge and self-efficacy have a significant association with anxiety in perimenopausal women. Various efforts to increase knowledge and to build self-efficacy are needed, such as an educational and support program to reduce anxiety in women approaching menopause.

Keywords: knowledge, body image perception, self-efficacy, anxiety

Cite This Article: Teja, N.M.A.Y.R., Ekawati, N.K., Wulanyani, N.M.S. 2019. The correlation between knowledge, body image perception and self efficacy with anxiety among perimenopausal women in Dauh Puri Klod Village, Bali. Public Health and Preventive Medicine Archive 7(1): 26-31. D0l:10.15562/phpma.v7i1.190

${ }^{1}$ Public Health Postgraduate Program, Faculty of Medicine, Udayana University,

${ }^{2}$ Department of Public Health and Preventive Medicine, Faculty of Medicine, Udayana University, ${ }^{3}$ Department of Psychology, Faculty of Medicine, Udayana University
${ }^{*}$ Correspondence to:

Ni Made Ayu Yulia Raswati Teja,

Public Health Postgraduate Program, Faculty of Medicine, Udayana University,

ayuteja.stikesbali@gmail.com

\section{INTRODUCTION}

Globally, the number of people experiencing anxiety in 2015 was estimated at 264 million, and the highest proportion was reported in Southeast Asia at $23 \% .{ }^{1}$ It was also reported that the proportion of anxiety in women increased at the age of 40-49 years. Prevalence of menopausal depression in Asia in 2011 was $47 \%$ and in 2013 it was reported to increase to 66\%. ${ }^{2}$ The 2013 Indonesia Basic Health Research (Riskesdas) shows that the prevalence of emotional disorders in Indonesia in the population aged 15 years and over was $6 \%$ or around 14 million people; this increased to $9.8 \%$ in $2018{ }^{3.4}$ The proportion of emotional disorders was higher in women compared to men, and has increased in the age group 45-54 to 75 years and above. ${ }^{3,4}$

During menopause women experience hormonal fluctuations that result in physical and emotional changes which cause psychological symptoms including depression, irritability, suspicion, anxiety, insomnia and restlessness. ${ }^{5}$ Continuous anxiety can lead to depression in menopausal women. ${ }^{6}$
High self-efficacy is reported to reduce anxiety and improve the quality of life among perimenopausal women. ${ }^{7}$ An individual with high self-efficacy will be more able to adapt to changes, including facing menopause. ${ }^{8}$ Some studies conducted in Indonesia found that knowledge is associated with anxiety in postmenopausal women. ${ }^{9,10}$ Qualitative study reports show that anxiety is associated with worry about physical changes during menopause. ${ }^{11}$ Quantitative studies on physical changes show that there is a relationship between physical changes in women aged $40-50$ years with anxiety during menopause. ${ }^{12}$

Studies on anxiety in women approaching menopause are still needed, especially regarding body image perception and self-efficacy. This study aims to determine the association between knowledge, perception of body image and self-efficacy with anxiety in menopausal women.

\section{METHODS}

A cross sectional survey was conducted in August 2018 in Dauh Puri Klod Village, West Denpasar 
District, Denpasar City, Bali Province. A sample of 87 respondents was selected with systematic random sampling from 1,039 women aged 45-55 years recorded in the village of Dauh Puri Klod. Eligible respondents were women aged $45-55$ years and had begun menopause. If at the time of the home visit it turned out that women aged 45-55 years were still menstruating, then they were replaced with the next women in the list. The sample size was calculated based on the proportion of perimenopausal women with sufficient knowledge who experienced severe anxiety of $32 \%$; proportion of perimenopausal women with insufficient knowledge who experienced anxiety of 53\%; confidence level of $95 \%$ and power of $80 \% .^{13}$

Data collection was conducted by interviewing each respondent in their house using a questionnaire that had been pre-tested on five menopausal women. The data collected consisted of five components namely respondent characteristics, knowledge, body image perception, self-efficacy and anxiety. Questions about knowledge amounted to 10 items consisting of understanding on the menopause period, types of menopause and menopausal symptoms. Questions of the body image perception referred to the Abdul's theory, where the perception of body image consisted of two aspects, namely adaptive and maladaptive. Questions about body image perception consisted of 19 items ${ }^{14}$ and questions about self-efficacy was referring to Bandura's theory, which consisted of nine items involving

Table 1 Characteristics of respondents

\begin{tabular}{lcc}
\hline Variables & $\mathbf{n}$ & $\%$ \\
\hline Age & 27 & 31.0 \\
$45-49$ & 60 & 69.0 \\
$50-55$ & & \\
Ethnicity & 59 & 67.8 \\
$\quad$ Balinese & 28 & 32.2 \\
$\quad$ Javanese & & \\
Education & 13 & 14.9 \\
$\quad$ No schooling & 15 & 17.2 \\
$\quad$ Elementary & 41 & 47.1 \\
Secondary & 18 & 20.7 \\
$\quad$ Tertiary & & \\
Work status & 16 & 18.4 \\
$\quad$ Unemployed & 71 & 81.6 \\
$\quad$ Employed & & 51.7 \\
Family income & 45 & 48.3 \\
$\quad \geq$ IDR 3,500,000 & 42 & 100.0 \\
$\quad<$ IDR 3,500,000 & 87 & \\
Total & &
\end{tabular}

three dimensions namely magnitude, strength and level. ${ }^{15}$ Questions about anxiety facing menopause referred to Blackburn and Davidson's theory that consisted of 21 items with aspects of mood, cognitive, behavioral, motivational and biological reactions. ${ }^{16}$

The score of each item in each section is summed up so that the total score is obtained for each section, namely the total score of knowledge, perception of body image, self-efficacy and anxiety. Furthermore, the total score of each section is grouped into two categories based on the median value. Knowledge and self-efficacy are categorized as "good" if the score is equal to or above the median and "poor" if the score is below the median. Body image perception is categorized as "positive" if the score is equal to or above the median and "negative" if the score is below the median. Anxiety is categorized as "high" if the score is equal to or above the median and "low" if the score is below the median.

Bivariate analysis was performed with pearson correlation and chi square test, while multivariate analysis conducted with the backward method binary logistic regression. The correlations between anxiety and other variables are categorized as "strong" if the coefficient correlations are from 0.61 to 0.8 , "moderate" if the coefficient correlations are 0.4-0.6 and "weak" if the coefficient correlations are less than $0.4 .^{17}$

This study has been approved by the Ethics Committee of the Faculty of Medicine, Udayana University/Sanglah General Hospital on July 23, 2018.

\section{RESULTS}

Table 1 shows the characteristics of 87 respondents by age, ethnicity, education, work status and family income. Most respondents are 50-55 years old (69.0\%), have secondary and tertiary education (67.8\%), employed (81.6\%) and have an average income of IDR 3,500,000.

Table 2 shows the distribution of respondents by knowledge, body image perception, self-efficacy and anxiety. It was obtained that the median of knowledge score is 7 , perception of body image 54, self efficacy 27 and anxiety 27 . Each variable was then grouped into two categories with the median value as the cut off point.

In Table 3 the correlation coefficients between variables are presented and it appears that knowledge, self-efficacy and perception of body image are significantly correlated with anxiety. Knowledge and perception of body image are significantly correlated, with a positive direction (0.434) which means the higher the knowledge score is followed by the higher perception of body image score. Knowledge and self-efficacy are also significantly 
Table 2 Distribution of respondents by knowledge, perception of body image, self-efficacy and anxiety

\begin{tabular}{lcc}
\hline Variables & $\mathbf{n}$ & $\%$ \\
\hline Knowledge & & \\
$\quad$ Good & 47 & 54.0 \\
$\quad$ Poor & 40 & 46.0 \\
Perception of body image & & \\
$\quad$ Positive & 48 & 55.2 \\
$\quad$ Negative & 39 & 44.8 \\
Self-efficacy & & \\
$\quad$ Good & 46 & 52.9 \\
$\quad$ Poor & 41 & 47.1 \\
Anxiety & & \\
$\quad$ High & 45 & 51.7 \\
$\quad$ Low & 42 & 48.3 \\
Total & 87 & 100.0 \\
\hline
\end{tabular}

Table 3 Correlation coefficients between knowledge, body perception, self-efficacy and anxiety

\begin{tabular}{lcccc}
\hline & Knowledge & Body perception & Self-efficacy & Anxiety \\
\hline Knowledge & & & & \\
$\quad$ Pearson Correlation & 1 & .434 & .652 & -.668 \\
$\quad$ Sig (2-tailed) & & .000 & .000 & .000 \\
Body perception & & & & \\
$\quad$ Pearson Correlation & .434 & & .533 & -.472 \\
$\quad$ Sig (2-tailed) & .000 & .533 & .000 & .000 \\
Self-efficacy & & .000 & 1 & -.606 \\
$\quad$ Pearson Correlation & .652 & & & .000 \\
$\quad$ Sig (2-tailed) & .000 & -.472 & -.606 & 1 \\
Anxiety & & .000 & .000 & \\
$\quad$ Pearson Correlation & -.668 & & & \\
$\quad$ Sig (2-tailed) & .000 & & & \\
\hline
\end{tabular}

Table 4 Association between anxiety with knowledge, body perception and self-efficacy

\begin{tabular}{|c|c|c|c|c|c|}
\hline \multirow[b]{3}{*}{ Variable } & \multicolumn{4}{|c|}{ Anxiety } & \multirow{3}{*}{$\mathbf{p}$} \\
\hline & \multicolumn{2}{|c|}{ High } & \multicolumn{2}{|c|}{ Low } & \\
\hline & $\mathbf{n}$ & $\%$ & $\mathbf{n}$ & $\%$ & \\
\hline Knowledge & & & & & $<0.01$ \\
\hline Good & 11 & 23.4 & 36 & 76.6 & \\
\hline Poor & 34 & 85.0 & 6 & 15.0 & \\
\hline Body perception & & & & & 0.01 \\
\hline Positive & 19 & 39.6 & 29 & 60.4 & \\
\hline Negative & 26 & 66.7 & 13 & 33.3 & \\
\hline \multicolumn{6}{|l|}{ Self-efficacy } \\
\hline Good & 13 & 28.3 & 33 & 71.7 & $<0.01$ \\
\hline Poor & 32 & 78.0 & 9 & 22.0 & \\
\hline Total & 45 & 51.7 & 42 & 48.3 & \\
\hline
\end{tabular}


Table 5 Adjusted odd ratios between knowledge, self-efficacy and body perception with anxiety

\begin{tabular}{lcccc}
\hline & & \multicolumn{3}{c}{$\mathbf{9 5 \% \mathbf { C l }}$} \\
\cline { 3 - 5 } Variable & AOR & Lower & Upper & p \\
\hline Knowledge & 10.83 & 3.31 & 35.37 & 0.01 \\
Self-efficacy & 3.48 & 1.09 & 11.14 & 0.04 \\
Body perception & 0.395 & 0.087 & 1.697 & 0.23 \\
\hline
\end{tabular}

correlated and the correlation direction is positive (0.652), which means the higher the knowledge score is followed by the higher the self-efficacy score. Knowledge and anxiety variables have a strong and significant correlation, but with a negative direction $(-0.668)$ which means that the higher the knowledge score is followed by the lower the anxiety score. Body image perception and self-efficacy are significantly correlated and the correlation direction is positive (0.533) which means that the higher the body image perception score is followed by the higher the self-efficacy score. The variables of perception of self-image and anxiety have a fairly strong and significant correlation but with a negative direction $(-0.472)$ which means that the higher the body image perception score, the lower the anxiety score. The variables of self-efficacy and anxiety have a strong and significant correlation but with a negative direction $(-0.606)$ which means the higher the self-efficacy score, the lower the anxiety score.

Table 4 shows that there is an association between anxiety, knowledge, body image perception and self-efficacy after being grouped into two categories. Respondents with knowledge in the "good" category have a significantly $(\mathrm{p}<0.01)$ lower proportion of high anxiety than respondents with knowledge in the "poor" category, namely $23.4 \%$ and $85.0 \%$ respectively. Respondents with "positive" perceptions of body image also have a significantly $(\mathrm{p}=0.012)$ lower proportion of high anxiety than those with "negative" perceptions of body image, namely $39.6 \%$ and $66.7 \%$ respectively. Respondents with "good" self-efficacy have a significantly $(\mathrm{p}<0.01)$ lower proportion of high anxiety compared to respondents with "poor" self-efficacy, namely $28.3 \%$ and $78.0 \%$ respectively.

In Table 5, the results of multivariate analysis shows that the variables significantly associated with anxiety are knowledge (AOR=10.83; 95\%CI: 3.31-35.37) and self-efficacy (AOR=3.48; 95\%CI: 1.09-11.14), while the body image perception is not associated with anxiety (AOR=0.395; 95\%CI: 0.087-1.697).

\section{DISCUSSION}

The purpose of this study is to explore the association between knowledge, perception of body image and self-efficacy with anxiety levels among perimenopausal women. The results showed that the anxiety levels among women approaching menopause was significantly associated with knowledge and self-efficacy, but was not associated with perceptions of body image. The higher the knowledge and self-efficacy, the lower the anxiety of the respondents.

The results of this study are similar to the results of studies conducted in Genuksari Village, District of Genuk, Semarang City and Melur Pekanbaru Health Center which showed that there was a significant association between knowledge and anxiety in women who were facing menopause. ${ }^{9,10}$ Another study conducted in the Darmo Subdistrict Wonokromo Subdistrict, Surabaya also indicated that there was an association between knowledge and anxiety in perimenopausal women. ${ }^{13}$

The association between knowledge and anxiety in our study may be due to the influence of higher level of knowledge in how people react to myths which then affects their emotions. Respondents who have good knowledge about menopause may be more rational in accepting changes due to menopause, so that their emotions become more positive, and vice versa. Lack of knowledge about menopause is likely to cause anxiety when approaching menopause. ${ }^{9}$

Our study found that self-efficacy was associated with anxiety. This result is consistent with the result of a study conducted in Isfahan Mumbai which showed that there was an association between self-efficacy with depression and anxiety in middle-aged women. ${ }^{18}$ Self-efficacy is a psychological condition that is related to an individual's confidence in her ability to deal with something. The confidence that respondents have is found to affect feelings of anxiety that arise during the period before menopause. Respondents may feel confident that they can go through menopause, feel confident that they cope with symptoms and believe that menopause is a part of life that must be passed. This is not the case with respondents with less self-efficacy. ${ }^{19}$ According to Bandura, high self-efficacy can reduce anxiety, where the higher one's self-efficacy, the more active efforts are made to overcome obstacles or problems in life. ${ }^{20}$ Akker also stated that on the contrary, 
low self-efficacy can cause someone to interpret changes in menopause in a negative direction which results in anxiety. ${ }^{8}$

In our study, body image perceptions were not found to be associated with anxiety, possibly because of the lack of clarity in the differences in indicators measured through the body image perception questionnaire with indicators on the knowledge and self-efficacy questionnaires. A significant association between the perception of body image with knowledge and self-efficacy can also indicate the possibility of multicollinearity. Another possibility is adaptive to new condition where respondents have experienced menopause for a long time, that is one year, so there is a possibility of mixing information provided, between perceptions before menopause with perceptions when retrieving data, when there might be a process of accepting the menopausal conditions. In addition, another possibility is that the presence of media also influences the perception of menopausal women. ${ }^{21}$ Currently, in print and visual media, many middle-aged female figures with bodies that are no longer perceived as "ideal" are still actively displayed. Some literature suggests that the cause of anxiety as one of the elements of depression during menopause is very diverse and the symptoms are shown more on the psychological aspects, therefore there needs to be a variety of studies to reveal it. ${ }^{22}$

The limitation of our study is that there is no validation and reliability tests for the instrument used in this study. Another weakness is the possibility of a recall bias because the information asked is an event in the past, particularly those who have experienced menopause in a longer time before the interview. In addition, our study is carried out only in urban areas and in one village so that extrapolating the results into the other contexts should be taken in caution.

\section{CONCLUSION}

Knowledge and self-efficacy have a significant association with anxiety in perimenopausal women. Various efforts to increase knowledge and to build self-efficacy are needed, such as an educational and support program to reduce anxiety in women approaching menopause.

\section{ACKNOWLEDGEMENT}

We would like to thank the Head of Dauh Puri Klod Village and all cadres in Dauh Puri Klod Village who have facilitated the implementation of and all respondents who have participated in this study.

\section{REFERENCES}

1. World Health Organization. Depression and other common mental disorders: Global health estimates. 2017. World Health Organization. Geneva.

2. Makara MT, Maria K, Jakiel G. Epidemilogy of the symptomps of menopause. Prz Menopauzalny. 2014;13(3):203-201

3. Ministry of Health of Indonesia. Riset Kesehatan Dasar (Riskesdas) Tahun 2013 [The 2013 Indonesia Basic Health Research]. Ministry of Health of Indonesia. Jakarta; 2013.

4. Ministry of Health of Indonesia. Riset Kesehatan Dasar (Riskesdas) Tahun 2018 [The 2018 Indonesia Basic Health Research]. Ministry of Health of Indonesia. Jakarta; 2018.

5. Proverawti A. Menopause dan sindrome premenopause [Menopause and premenopausal syndromes]. Yogyakarta: Nuha Medika; 2010.

6. Mulyani NS. Menopause akhir siklus menstruasi pada wanita di usia pertengahan [Menopause, the end of menstrual cycle in the middle aged women]. Yogyakarta: Nuha Medika; 2013.

7. Jafari F, Hadizadeh MH, Zabihi R, Ganji K. Comparison of depression, anxiety, quality of life, vitality and mental health between premenopausal and postmenopausal women. Climacteric: The Journal of The International Menopause Society. 2014;17(6):660-5.

8. Akker OB. Reproductive health psychology. First edition. London: John Wiley \& Sons, Ltd; 2012.

9. Damayanti FN. Hubungan tingkat pengetahuan dan upaya penanganan ibu dengan kecemasan dalam menghadapi menopause di Kelurahan Genuksari Kecamatan Genuk [The association between knowledge and women's effort with anxiety in facing menopause in Genuksari Village, Genuk Sub-District]. Dinamika Kebidanan. 2012; 2(1), $1-14$.

10. Lusiana N. Faktor-faktor yang berhubungan dengan kecemasan wanita dalam menghadapi menopause di Puskesmas Melur Pekanbaru tahun 2014 [Factors associated with women's anxiety in facing menopause at Melur Public Health Center Pekanbaru year 2014]. Kesehatan Komunitas. 2014;2(5):215-9.

11. Prasetya MR, Firmiana ME, Imawati R. Peran religiusitas mengatasi kecemasan masa menopause [The role of religiosity in controlling anxiety during menopause]. Jurnal AL-AZHAR Indonesia Seri Humaniora. 2012;1(3):145-57.

12. Lombogia M. Hubungan perubahan fisik dengan kecemasan wanita usia 40-50 tahun dalam menghadapi menopause di Kelurahan Papusungan Kecamatan Lembeh Selatan [The association between physical changes with anxiety among women aged 40-50 years in facing menopause in Papusungan Village South Lembeh Sub-District]. Juiperdo. 2014;3(2):36-42.

13. Isyana $\mathrm{N}$, Puspitasari N. Faktor yang mempengaruhi tingkat kecemasan pada wanita perimenopause [Factors associated with level of anxiety among perimenopausal women]. The Indonesian Journal of Public Health. 2007;4(1):35-42.

14. Muhith A. Pendidikan keperawatan jiwa: Teori dan aplikasi [Mental health nursing education: Theory and application]. Yogyakarta: CV Andi Offset; 2015.

15. Bandura A. Guide for constructing self efficacy scales. In Pajares F, Urdan TC. Self efficacy beliefs of adolescents. Grenwich: Information Age Publishing; 2005.

16. Blackburn I, Davidson K. Cognitive therapy for depression and anxiety. USA: Blackwell Science; 1995.

17. Sugiyono. Metode penelitian: kuantitatif, kualitatif dan R\&D [Research methods: Quantitative, qualitative and R\&D]. Bandung: Alfabeta; 2017.

18. Hosseini H, Moradi R, Kazemi A, Shahshahani MS. Determinats of physical activity in middle aged woman in Isfahan using the Health Belief Model. Journal of Education and Health Promotion. 2017;25(134):124-34. 
19. Lee MS, Kim JH, Park MS, Yang J, Ko YH, Ko SD, et al. Factors influencing the severity of menopause symptoms in Korean post-menopausal women. Journal of Korean medical science. 2010; 25: 758-65.

20. Bandura A, Adams NE. Analysis of Self-Efficacy Theory of Behavioral Change. Cognitive Therapy and Research. 1977;1(4):287-310.

21. Lee MS. Women's body image throughout the adult life span : Latent growth modeling and qualitative approaches. Iowa State University; 2013.
22. Erbil N. Attitudes towards menopause and depression, body image of women during menopause. Alexandria Journal of Medicine. 2018;54(3):241-246.

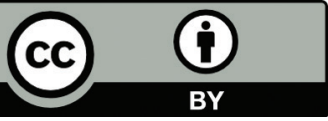

This work is licensed under a Creative Commons Attribution 